\title{
BIBLIA I NADZIEJA NA JEJ DOBRE TEUMACZENIE***
}

Powiedzenie, że Biblia dla Ojców Kościoła była wszystkim, jest niewątpliwie truizmem. Oni przecież ją nieustannie komentowali, nią żyli, na niej budowali swoje koncepcje i jej słowami, nawet nie cytując dosłownie i nie wspominając o niej, mówili w swoich dziełach. Wśród wczesnochrześcijańskich autorów byli jednak tacy, którzy w sposób szczególny zasłużyli się przyswajając mniej uczonym wiernym meandry wiedzy na temat Biblii, jak i zajmując się nią od strony naukowej - językowej, teologicznej i pasterskiej. Z pewnością do tych najbardziej zasłużonych należą św. Hieronim ${ }^{1}$ i św. Augustyn ${ }^{2}$. Ten pierwszy przede wszystkim jako niezrównany thumacz Pisma Świętego, a drugi jako interpretator. Wiele czasu i pism poświęcili nie tylko wyjaśnianiu słów natchnionych, ale także samym słowom i ich warstwie formalnej. Czynili to nie tylko wobec innych, w swych homiliach i traktatach, ale również dyskutując i spierając się ze sobą, w swoich listach ${ }^{3}$. Wydaje się, że właśnie w nich zawarli

* Ks. dr hab. Marcin Wysocki - adiunkt w Katedrze Patrologii Greckiej i Łacińskiej w Instytucie Historii Kościoła i Patrologii na Wydziale Teologii Katolickiego Uniwersytetu Lubelskiego Jana Pawła II; e-mail: mwysocki@kul.lublin.pl, orcid.org/0000-0001-5448-5566.

** Praca powstała w wyniku realizacji projektu badawczego o $\mathrm{nr}$ 2014/15/B/HS1/03851 finansowanego ze środków Narodowego Centrum Nauki w Krakowie.

${ }^{1} \mathrm{Na}$ temat Hieronima jako thumacza zob. G.Q.A. Meershoek, Le latin biblique d'après saint Jérôme, Latinitas Christianorum Primaeva 20, Nijmegen - Utrecht 1966; J.T. Cummings, St. Jerome as Translator and as Exegete, StPatr 22 (1975) 279-282; U. Köpf, Hieronymus als Bibelübersetzer, w: Eine Bibel - Viele Übersetzungen. Not und Notwendigkeit, hrsg. S. Meurer, Stuttgart 1978, 71-89; A. Eckmann, Hieronim ze Strydonu. Nauka w stużbie rozumienia i interpretacji Pisma Świętego, AK 422 (1979) 422-429; M. Gilbert, Saint Jérôme, traducteur de la Bible, w: tenże, Il a parlé par les prophètes. Thèmes et figures bibliques, Namur 1998, 9-28; L. Gamberale, Problemi di Gerolamo traduttore fra lingua, religione e filologia, w: Cultura latina cristiana. Fra terzo e quinto secolo. Atti del Convegno, Mantova, 5-7 novembre 1998, ed. C. Gallico, Firenze 2001, 311-345; J.N.D. Kelly, Hieronim. Życie, pisma, spory, thum. R. Wiśniewski, Warszawa 2003, 163-192; M. Meiser, Hieronymus als Textkritiker, w: Die Septuaginta - Texte, Theologien, Einflüsse. 2. Internationale Fachtagung veranstaltet von Septuaginta Deutsch (LXX.D), Wuppertal 23.-27. Juli 2008, hrsg. W. Kraus - M. Karrer M. Meiser, Wissenschaftliche Untersuchungen zum Neuen Testament 252, Tübingen 2010, 256-271; L. Gamberale, San Gerolamo. Intellettuale e filologo, Storia e Letteratura 282, Roma 2013.

${ }^{2}$ Por. M. Pontet, L'exégèse de St. Augustin predicateur, Paris 1945; D.S. Chidester, The Symbolism of Learning in St. Augustine, HTR 76 (1983) 73-90; M. Simonetti, Między dostownościq a alegoriq. Przyczynek do historii egzegezy patrystycznej, tłum. T. Skibiński, Kraków 2000, 347-364.

${ }^{3} \mathrm{O}$ korespondencji między Hieronimem a Augustynem zob. F.E. Torscher, The Correspondence 
najwięcej bezpośrednich informacji dotyczących sposobów tłumaczenia słów Pisma Świętego, jego wersji, istniejących tłumaczeń, czyli literackiej strony Biblii, bo interpretacji jest w nich oczywiście całe mnóstwo.

W zacytowanym przez św. Hieronima wstępie Cycerona do jego thumaczenia mów Ajschinesa i Demostenesa, ten wielki retor i językoznawca pisał, że ma nadzieję, iż dobrze wyraził ich myśl w tłumaczeniu, wykorzystując wszystkie ich zalety ${ }^{4}$. Tę nadzieję podzielali także Augustyn i Hieronim nie tylko thumacząc, ale i oceniając inne tłumaczenia Biblii i różnych dzieł starożytnych. Warto zatem przyjrzeć się, co ci dwaj badacze Pisma Świętego z przełomu IV i V wieku mówią w swojej korespondencji o warstwie lingwistycznej Biblii i sposobie jej thumaczenia (i nie tylko) oraz jakie nadzieje pokładają w tych, którzy tę Księgę nadziei thumaczą 5 .

1. Dzieło. Aby mówić o znaczeniu i ważności przekładów i procesu tłumaczenia, należy najpierw zacząć od samego dzieła, które ma być przedmiotem thumaczenia - Pisma Świętego - i jego znaczenia dla naszych autorów. Augustyn w liście 105, skierowanym do donatystów podkreśla wspólne dziedzictwo Pisma Świętego pisząc:

„W Piśmie nauczyliśmy się Chrystusa, w Piśmie nauczyliśmy się Kościoła. Wspólnie posiedliśmy Pismo, dlaczego więc wspólnie w nim nie trzymamy się Chrystusa i Kościoła?"6

Zaś w liście 120. Augustyn daje wyjątkowe wskazówki odnośnie do jego znaczenia. Pisze zwracając się do Konsencjusza:

„Kochaj tę wiedzę bardzo, ponieważ samo Pismo Święte, które inspiruje nas wiara, zapowiedzią wiedzy, może być bezużyteczne, jeżeli nie zrozumiesz go właściwie. Wszyscy heretycy, którzy przyjmuja jego autorytet uważają, że postępują za nim, podczas gdy w rzeczywistości postępują za swymi błędami

of St. Augustine and St. Jerome. A Study, „The American Ecclesiastical Review” 57 (1917) 476-492; T. Haitjema, De briefwisseling tuschen Augustinus en Hieronymus, „Tijdschrift voor Geschiedenis” 36 (1921) 159-198; D. De Bruyne, La correspondence échangée entre Augustin et Jèrôme, ZNW 31 (1932) 233-248.

${ }^{4}$ Por. Hieronymus, Epistula 57, 5.

${ }^{5} \mathrm{~W}$ bibliografii dotyczącej korespondencji Hieronima i Augustyna brak jest niestety opracowań dotyczących sztuki translatorskiej i sposobu przekładania Biblii. W języku polskim istnieje artykuł D. Spychały (Św. Hieronim i św. Augustyn wobec tlumaczeń Biblii i literatury antycznej, „Saeculum Christianum" 15 (2008) 2, 5-13), jednak autor poza ukazaniem życia obu autorów, znaczenia Biblii w chrześcijaństwie, streszczeniem listów i pokrótce stosunku obu do literatury antycznej, nie zagłębia się w kwestie tłumaczenia Biblii i innych dzieł.

${ }^{6}$ Augustinus, Epistula 105, 14, CSEL 34/2, 605: „In Scripturis didicimus Christum, in Scripturis didicimus Ecclesiam. Has Scripturas communiter habemus; quare non in eis et Christum et Ecclesiam communiter retinemus?", tłum. własne. 
i są heretykami dlatego właśnie, że nie rozumieją Pisma, a nie dlatego, że je odrzucają"7.

Pismo Święte musi być zatem właściwie rozumiane, czemu pomagają odpowiednie thumaczenia. Nierozumienie Pisma jest początkiem błędu, który objawiał się w różnych herezjach. Dlatego obaj autorzy z jednej strony zwracają uwagę na szacunek i cześć, jakimi należy otaczać to podstawowe źródło wiary, a z drugiej strony wskazują na ludzką słabość, która może prowadzić do wspomnianych powyżej błędów i nieporozumień. Hieronim w liście 53. mówi o języku Pisma, który może wydawać się zbyt prosty i pospolity - co było zresztą przecież przyczyną odejścia Augustyna do manicheizmu i poszukiwania wiary bliższej klasycznej doskonałości - oraz stwierdza, że moga w tłumaczeniach występować błędy zawinione przez tłumaczy, ale można spojrzeć na tę prostotę i zwyczajność Pisma Świętego jako na środek służący łatwiejszemu zrozumieniu Pisma przez ludzi prostych, a także służący możliwej wielości interpretacji zależnych od wykształcenia czytelnika ${ }^{8}$. Augustyn zaś w korespondencji z Hieronimem zdobywa się na osobiste wyznanie:

„Wyznam ci bowiem, że nauczyłem się takim szacunkiem i czcią otaczać księgi Pisma świętego zaliczone do Kanonu, że najmocniej wierzę, że żaden $\mathrm{z}$ ich autorów pisząc $\mathrm{w}$ niczym się nie pomylił. Jeśli zaś natknę się $\mathrm{w}$ nich na coś, co wydawałoby się niezgodne z prawda, to nie będę się wahał przypuszczać, że albo kodeks jest błędny albo tłumacz nie pojął treści tekstu, albo ja nie zrozumiałem".

Hieronim w liście do Pammachiusza stwierdza wyraźnie, że to właśnie wadliwe i błędne thumaczenia ludzi niedoświadczonych i nie znających dobrze języka utrudniają właściwe zrozumienie Pisma Świętego. Jednocześnie Betlejemczyk podkreśla, że tłumaczenie kościelne nie powinno posługiwać się językiem jałowych szkół filozoficznych, czyli zbyt ozdobnym, pełnym wdzięku, ale właśnie prostym, choć tego wdzięku nie pozbawionym. Ma trafiać bowiem do całego rodzaju ludzkiego, a nie tylko do wybranych i wykształconych ${ }^{10}$.

Szczególną estymą obaj autorzy otaczają podstawowe w ich czasach thumaczenie Starego Testamentu, jakim była Septuaginta - natchnione thuma-

${ }^{7}$ Tenże, Epistula 120, 13, CSEL 34/2, 716: „Intellectum uero ualde ama; quia et ipsae Scripturae sanctae, quae magnarum rerum ante intellegentiam suadent fidem, nisi eas recte intellegas, utiles tibi esse non possunt. Omnes enim haeretici, qui eas in auctoritate recipiunt, ipsas sibi uidentur sectari, cum suos potius sectentur errores; ac per hoc non quod eas contemnant, sed quod eas non intellegant, haeretici sunt", thum. własne.

${ }^{8}$ Por. Hieronymus, Epistula 53, 10.

${ }^{9}$ Augustinus, Epistula 82, 3, CSEL 34/2, 354: „Ego enim fateor Caritati tuae, solis eis Scripturarum libris qui iam canonici appellantur, didici hunc timorem honoremque deferre, ut nullum eorum auctorem scribendo aliquid errasse firmissime credam. Ac si aliquid in eis offendero Litteris, quod uideatur contrarium ueritati; nihil aliud, quam uel mendosum esse codicem, uel interpretem non assecutum esse quod dictum est, uel me minime intellexisse, non ambigam", ŹMT 63, 3*.

${ }^{10}$ Por. Hieronymus, Epistula 48, 4. 
czenie siedemdziesięciu thumaczy dokonane w Aleksandrii w okresie od III do I wieku przed Chr. Obaj podkreślają wyjątkową powagę, jaką cieszy się Biblia w wersji Siedemdziesięciu Tłumaczy ${ }^{11}$. Hieronim, wskazując na pewne niedociagnnięcia w greckiej wersji Starego Testamentu, podkreśla jednak, że

„wydanie Septuaginty przyjęło się słusznie w Kościołach, czy to dlatego, że jest pierwsze i powstało przed przyjściem Chrystusa, czy że używane było [...] przez Apostołów"12.

To sposób tłumaczenia i postępowania z tekstem ksiąg świętych, czy to Siedemdziesięciu Tłumaczy, czy to Apostołów, jest dla Hieronima wzorem i odniesieniem $^{13}$. Augustyn przywołuje szacunek i obeznanie z Septuagintą wiernych Kościoła, których „uszy i serca przywykły do tłumaczenia zatwierdzonego nawet przez Apostołów"14. W związku z tym niechętnie przyjmują oni nowe thumaczenia ${ }^{15}$. Prosi on także Hieronima, ze względu na ludzi, ale przede wszystkim powagę i autorytet przekładu Siedemdziesięciu Tłumaczy, aby to właśnie na nim oparł swoje tłumaczenie ksiag kanonicznych Pisma Świętego $^{16}$. Hieronim zaś, niejako w odpowiedzi, zaleca Augustynowi czytanie ksiagg Siedemdziesięciu Thumaczy w stanie czystym, w takim, jakim zostały przez nich wydane, a nie z poprawkami i uzupełnieniami późniejszych thumaczy i redaktorów ${ }^{17}$.

Obaj autorzy, w tych kilku spośród licznych wypowiedzi, podkreślają wyjątkowość Pisma Świętego i ogromne znaczenie przede wszystkim istniejącego thumaczenia Starego Testamentu na język grecki - Septuaginty, ale jednocześnie zarysowują tematykę, która jest podstawowym tematem niniejszego opracowania - kwestie językowej strony Pisma Świętego. Podkreślają istotową doskonałość Bożego Słowa, a jednocześnie możliwe błędy i pominięcia wynikające z ludzkiej niedoskonałości.

2. Człowiek. Jak można to zauważyć w powyższych wypowiedziach, zawartych w listach Augustyna i Hieronima, obaj dostrzegają, że tym, który może wprowadzić niezrozumienie i błędy w thumaczone dzieło, w tekst Pisma Świętego, jest człowiek, przede wszystkim tłumacz odpowiedzialny za przekład tekstu świętego. Obaj zdają sobie sprawę, że za tłumaczenie Świętych Ksiąg brali się różni ludzie. Augustyn, interpretując i omawiając różne zagadnienia

\footnotetext{
${ }^{11}$ Por. Augustinus, Epistula 71, 4-5; 82, 35; Hieronymus, Epistula 112, 19.

${ }^{12}$ Hieronymus, Epistula 57, 11, ŹMT 55, 66: „et tamen iure Septuaginta editio obtinuit in ecclesiis, vel quia prima est et ante Christi fertur adventum vel quia ab apostolis [...] usurpata”, ŹMT $55,66^{*}$.

${ }^{13}$ Por. tenże, Epistula 57, 7.

${ }^{14}$ Augustinus, Epistula 82, 35, CSEL 34/2, 386: „quarum aures et corda illam interpretationem audire consueuerunt, quae etiam ab Apostolis approbata est", ŹMT 63, 20*.

${ }^{15}$ Por. tenże, Epistula 71, 5.

${ }^{16}$ Por. tenże, Epistula 71, 4.

${ }^{17}$ Por. Hieronymus, Epistula 112, 19.
} 
wynikające z Biblii, często sięgał po wyjaśnienia językowe - znaczenie słów, składnię - także korzystając z istniejących wówczas przekładów. W liście 149,

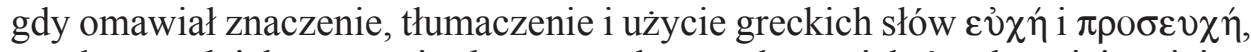
przełożonych jako oratio i adoratio, wskazywał na ,niektórych mniej umiejętnych thumaczy" (nonnulli minus erudite intuentes), którzy niepoprawnie przetłumaczyli te dwa terminy ${ }^{18}$. W tym samym liście stwierdził, że „wśród nas możemy znaleźć kilku tłumaczy, którzy mieli problemy z przełożeniem tych słów uważnie i rozumnie"19. Zaś w liście do Hieronima Hippończyk prosił o przesłanie jego tłumaczenia Septuaginty, po to, aby mógł przestać używać „niedołężnego przekładu łacińskich tłumaczy, którzy się na to odważali”"20. Skoro istnieją nieporadni tłumacze, tacy, którzy pomimo swych braków odważyli się na tłumaczenie tekstu Biblii, którzy nie dokonali tego z właściwą wiedzą i doświadczeniem, zatem wydaje się, że Augustyn musi stawiać wobec osoby zajmującej się thumaczeniem tekstu Pisma Świętego pewne wymagania.

Biorąc pod uwagę powyżej przedstawione zastrzeżenia wysuwane przez Augustyna, można stwierdzić, że, według niego, tłumacz powinien odznaczać się wiedzą i mądrością. W innych jednak fragmentach swych listów obaj autorzy ukazują szczegółowiej wymagania stawiane tłumaczom. Na pierwszym miejscu wymagana jest oczywiście od tłumacza dogłębna znajomość obu języków - z którego i na który tłumaczony jest tekst Pisma Świętego. Tłumacz powinien posiadać wiedzę na temat znaczenia poszczególnych słów i odznaczać się bogatym słownictwem ${ }^{21}$. W przywołanym zaś liście do Hieronima Augustyn najpierw ukazuje, w jaki sposób tłumacz powinien pracować nad tekstem thumaczenia Pisma świętego, a następnie cechy, którymi odznacza się Hieronim, a które powinny być także cechami każdego dobrego tłumacza. Warto w tym miejscu przywołać dosłownie słowa Hippończyka, w których ukazuje swoje pragnienia i swój obraz thumacza:

„Co do mnie, wolałbym, żebyśmy pracowali nad Pismem Świętym raczej poważnie, nie dla rozrywki. Przypuszczam, że użyłeś tego wyrazu dla ułatwienia sprawy. Ja - przyznaję - czegoś więcej wymagam od ciebie znając twoje wielkie zdolności, inteligencję, wykształcenie nabyte w ciagu wielu lat studiów i pracy naukowej i zadziwiająca dokładność. Duch Święty nie tylko ci to wszystko daje, ale także dyktuje, abyś mnie wspierał w ważnych i trudnych kwestiach, nie wtedy, gdy nad Pismem Świętym szukam miłego spędzenia czasu, lecz kiedy się męczę jak wędrowiec z trudem oddychający w górach"22.

${ }^{18}$ Augustinus, Epistula 149, 16, CSEL 44, 362, tłum. własne.

${ }^{19}$ Tenże, Epistula 149, 12, CSEL 44, 359: ,nam nostri interpretes uix reperiuntur, qui ea diligenter et scienter transferre curauerint", tłum. własne.

${ }^{20}$ Tenże, Epistula 82, 35, CSEL 34/2, 386: , et tanta Latinorum interpretum, qui qualescumque hoc ausi sunt, quantum possumus imperitia careamus", ŹMT 63, 20*.

${ }^{21}$ Por. tenże, Epistula 149, 16.

${ }^{22}$ Tenże, Epistula 82, 2, CSEL 34/2, 352-353: „Equidem quantum ad me attinet, serio nos ista, 
Augustyn nie pozostawia zatem wątpliwości co do sposobu pracy tłumacza z Pismem Świętym. To poważne zadanie, ale równie ważne są następujące dalej określenia: zdolności, inteligencja, wykształcenie, dokładność, a przede wszystkim asystencja Ducha Świętego. Jest bowiem thumacz niejako pierwszym interpretatorem świętego tekstu nadając mu swoiste znaczenie przez dobór odpowiednich słów. Wydaje się także, że ważne jest, aby tłumacz pamiętał i myślał o odbiorcach swego tłumaczenia, czytelnikach swego tekstu. Z pomocą Ducha Świętego ma on wspierać, pomagać, ożywiać i ułatwiać kontakt z natchnionym tekstem, aby można nim było z łatwością oddychać.

Augustyn wskazuje także, na możliwość zastosowania w tłumaczeniu osiagnięć współczesnych mu badaczy i interpretatorów Pisma. Mówiąc więc współczesną terminologią, tłumacz powinien być oczytany w literaturze dotyczącej danej Księgi czy ogólnie Pisma świętego, ale także znać inne istniejące thumaczenia, również na inne języki. W tymże liście bowiem zapytuje Hieronima, prosząc o przesłanie jego dzieła $O$ najlepszym sposobie tłumaczenia:

„nadto chciałbym wiedzieć, w jaki sposób tłumacz powinien łączyć znajomość języków z wykładami tych, którzy zajmują się objaśnianiem Pisma. Oni bowiem, choćby nawet wyznawali jedną, prawdziwą wiarę, z powodu niejasności wielu miejsc z konieczności muszą przekładać tekst w różny sposób, choćby ta różnorodność nie była sprzeczna z jednością ich wspólnej wiary"23.

Augustyn w innym z listów wychwala także cechy Hieronima, które pozwoliły mu wykonać tłumaczenie Księgi Hioba i które to cechy, jak się wydaje, powinny być także charakterystyczne dla wszystkich tłumaczy: „z godną podziwu dokładnością” (tam mirabili diligentia), „odznaczasz się niepospolitą bystrością" (uerumtamen quia praeuolas ingenio) ${ }^{24}$. Z pewnością dokładność i bystrość to cechy przydatne dobremu thumaczowi. Ważne jest także w przypadku tłumacza docenienie jego wysiłku, co może owocować chętniejszym udostępnieniem owoców swej pracy. Dlatego Hieronim w liście do Pammachiusza pisał:

„Jeśli się dowiem, że przeczytałeś szesnaście ksiąg prorockich, które z hebrajskiego przełożyłem na łacinę, i że rozkoszujesz się tym dziełem, będę się

quam ludo, agere mallem. Quod si hoc uerbum tibi propter facilitatem ponere placuit; ego fateor, maius aliquid expeto a benignitate uirium tuarum, prudentiaque tam docta, et otiosa, annosa, studiosa, ingeniosa diligentia; haec tibi non tantum donante, uerum etiam dictante Spiritu sancto, ut in magnis et laboriosis quaestionibus, non tamquam ludentem in campo Scripturarum, sed in montibus anhelantem adiuues", ŹMT 63, 2*.

${ }^{23}$ Tenże, Epistula 82, 34, CSEL 34/2, 386: „Librum quoque tuum, cuius mentionem fecisti, de Optimo genere interpretandi, cupio legere, et adhuc nosse quomodo coaequanda sit in interprete peritia linguarum, coniecturis eorum qui Scripturas edisserendo pertractant; quos necesse est, etiamsi rectae atque unius fidei fuerint, uarias parere in multorum locorum obscuritate sententias: quamuis nequaquam ipsa uarietas ab eiusdem fidei unitate discordet", ŹMT 63, 20*.

${ }^{24}$ Tenże, Epistula 71, 3, CSEL 34/2, 250-251, tłum. W. Eborowicz: Św. Augustyn, Listy (1-75), Pelplin 1983, s. 390. 
czuł zniewolony, by także i innych rzeczy nie trzymać zamkniętych w szafie. Przełożyłem niedawno Hioba na nasz język; [...]. Czytaj go po grecku i po łacinie i porównaj stare wydanie z moim przekładem, a jasno się przekonasz, jak wielka jest różnica między prawdą a kłamstwem"25.

Jednocześnie Augustyn w liście do Strydończyka wskazuje na pokorę i prawdziwy osąd thumacza o sobie samym ${ }^{26}$. Hieronim zwraca także naszą uwagę w innym liście na umiejętność dostosowania się tłumacza do rodzaju i gatunku tłumaczonego tekstu. Zauważa, że inną metodą należy tłumaczyć Pismo Święte - o tym sposobie za chwilę - a inną pozostałe teksty starożytne, np. mowy. Ukazuje przy tym przykłady wybitnych tłumaczy i teoretyków translatoryki - Cycerona, Horacego - których wypowiedzi potwierdzają metody stosowane przez Hieronima i jego poglądy na tłumaczenia ${ }^{27}$, choć także wskazuje na niedociągnięcia i swoiste błędy, np. Cycerona w sposobie przekładania ${ }^{28}$.

3. Sposób. Ostatnie zdania poprzedniego paragrafu nawiązały już bezpośrednio do metodologii tłumaczenia dzieł, zarówno Pisma Świętego, jak i dzieł świeckich, o czym obaj nasi autorzy wspominają w swojej korespondencji. Na tej podstawie, pozostawiając dzieło, które jest tłumaczone i człowieka, który je tłumaczy, należy przejść do trzeciego elementu, który musi być obecny, aby spełnić nadzieje na dobre tłumaczenie Pisma Świętego, ale i innych pism. Chodzi oczywiście o metodę tłumaczenia.

Obaj autorzy wiele miejsca w swoich listach, ale i innych pismach, o których wspominają w swojej korespondencji ${ }^{29}$, poświęcają omówieniu metod i sposobu tłumaczenia. Powołują się przy tym, jak już wcześniej zauważono, na autorytet i dzieła znamienitych tłumaczy i teoretyków starożytności ${ }^{30}$. Jeżeli chodzi o ukazywanie metodologii tłumaczenia, prym bezsprzecznie wiedzie Hieronim, co nie powinno dziwić, jako że jest tłumaczem uznanej później za oficjalne tłumaczenie kościelne Wulgaty, czyli całościowego prze-

${ }^{25}$ Hieronymus, Epistula 48, 4, ŹMT 54, 198: „Libros sedecim prophetarum, quos in Latinum de Hebraeo sermone uerti, si egeris et delectari te hoc opere conperero, prouocabis nos etiam cetera clausa armario non tenere. Transtuli nuper Iob in linguam nostram; [...]. Lege eundem raecum et Latinum et ueterem editionem nostrae translationi conpara, et liquido peruidebis, quantum distet inter ueritatem et mendacium", ŹMT 54, 198*.

${ }^{26}$ Por. Augustinus, Epistula 82, 3.

${ }^{27}$ Por. Hieronymus, Epistula 57, 5.

${ }^{28}$ Por. tenże, Epistula 57, 11.

${ }^{29} \mathrm{~Np}$. Hieronimowe dzieło $O$ najlepszym rodzaju thumaczenia oraz przedmowy do thumaczonych ksiagg, (por. tenże, Epistula 112, 20), czy też przedmowa do książki o życiu błogosławionego Antoniego (por. tamże, 57, 6).

${ }^{30}$ Jak wspomniano powyżej np. Hieronim przywołuje Marka Tuliusza Cycerona i jego thumaczenie Protagorasa Platona, O gospodarstwie Ksenofonta, mowy Ajschinesa i Demostenesa oraz teorię przekładu zawartą we wstępie do nich, ale także Sztukę poetyckq Horacego. Por. Hieronymus, Epistula 57, 5. 
kładu Starego i Nowego Testamentu na język łaciński ${ }^{31}$. To jednak Augustyn, doceniając wiedzę i umiejętności swego starszego kolegi, stawiał pytania, krytykował, wymagał, podpowiadał, i w ten sposób tworzył się swoisty dialog dotyczący sposobu thumaczenia Pisma Świętego. W liście 28. do Hieronima Hippończyk pisał o tłumaczeniu zarówno Biblii, jak i innych dzieł będących komentarzami do niej:

„Proszę więc, a ze mną prosi cała żądna wiedzy społeczność Kościołów afrykańskich, byś nie ociagając się dokładał starań w tłumaczeniu ksiąg autorów, którzy nasze Pismo Święte jak najlepiej po grecku komentowali. [...] Co się zaś tyczy przekładu na język łaciński świętych Pism kanonicznych, to nie chciałbym, byś się trudził nimi, chyba że w ten sposób, jak przetłumaczyłeś Ksieggę Hioba, to znaczy tak, żeby z dodanych znaków widoczne było, jaka zachodzi różnica między Twoim thumaczeniem a Septuagintą, która cieszy się szczególną powagą. A nie mogę się dość nadziwić, że w kodeksach hebrajskich znajduje się jeszcze coś, co uszło uwagi tylu tak bardzo doświadczonych thumaczy tego języka. Pomijam bowiem Siedemdziesięciu, o których umiejętności czy duchu zgodności większej niż gdyby jeden czynił to człowiek, nie śmiem stanowczego wydać wyroku, a tylko sądzę, że należy im w tej dziedzinie bez zastrzeżeń przyznać najwyższą powagę; więcej mnie obchodzą późniejsi tłumacze. $\mathrm{Ci}$ - jak wiadomo - bardziej niewolniczo trzymając się reguł przy słowach i wyrażeniach hebrajskich, nie tylko nie zgadzali się ze sobą, ale nawet pozostawili wiele rzeczy, które po tak długim czasie należy wydobywać i wyjaśniać. Jeżeli bowiem niejasne są, trzeba przypuszczać, że i Ty możesz się w nich mylić, jeśli jasne, nie chce się wierzyć, że oni mogli się w nich pomylić. Na miłość Twą zaklinam Cię, byś wyjaśniwszy przyczyny tego zechciał mi je podać" 32 .

${ }^{31}$ O Wulgacie zob. K. Bardski, Wulgata, EK 20, 1027-1030, A. Żurek, Od Septuaginty do Wulgaty - Biblia w kościele pierwszych wieków, TwStT 11 (1992) 99-107; I. Gano, Hieronim jako autor Wulgaty, ŻM 5/6 (1955) 140-154; J. Królikowski, Jak powstała Wulgata i któremu tekstowi Pisma Świętego przystuguje to miano?, TwStT 36 (2017) 5-20.

32 Augustinus, Epistula 28, 2, CSEL 34/1, 105-107: „Petimus ergo, et nobiscum petit omnis Africanarum Ecclesiarum studiosa societas ut interpretandis eorum libris, qui graece Scripturas nostras quam optime tractauerunt, curam atque operam impendere non graueris. Potes enim efficere ut nos quoque habeamus tales illos uiros, et unum potissimum, quem tu libentius in tuis litteris sonas. De uertendis autem in latinam linguam sanctis Litteris canonicis laborare te nollem, nisi eo modo quo Iob interpretatus es; ut signis adhibitis quid inter hanc tuam et LXX, quorum est grauissima auctoritas, interpretationem distet, appareat. Satis autem nequeo mirari, si aliquid adhuc in hebraeis exemplaribus inuenitur, quod tot interpretes illius linguae peritissimos fugerit. Omitto enim LXX, de quorum uel consilii uel spiritus maiore concordia, quam si unus homo esset, non audeo in aliquam partem certam ferre sententiam, nisi quod eis praeeminentem auctoritatem in hoc munere sine controuersia tribuendam existimo. Illi me plus mouent, qui cum posteriores interpretarentur, et uerborum locutionumque hebraearum uiam atque regulas mordicus, ut fertur, tenerent, non solum inter se non consenserunt, sed etiam reliquerunt multa, quae tanto post cruenda et prodenda remanerent. Et aut obscura sunt, aut manifesta: si enim obscura sunt, te quoque in eis falli posse creditur; 
Ten długi fragment należało przytoczyć w całości, aby ukazać z jednej strony istotę sporu, który rozgorzał pomiędzy tymi dwoma wybitnymi egzegetami $\mathrm{V}$ wieku ${ }^{33}$, a z drugiej, aby ukazać interesujący nas wątek sposobu tłumaczenia Biblii. Augustyn, zwracając się do Hieronima, podkreśla znaczenie Septuaginty i przede wszystkim prosi o wskazanie miejsc skażonych, błędnych i poprawionych, zwracając uwagę, że również Strydończyk może pobłądzić. Aby tego uniknąć prosi o ukazanie metody tłumaczenia. Podobne prośby zawarł Hippończyk $\mathrm{w}$ liście $71^{34}$, w którym jednocześnie $\mathrm{z}$ jednej strony pochwala Hieronimowe tłumaczenie Ewangelii z języka greckiego, a z drugiej ostrzega przed możliwymi błędami i - co w sporze o tłumaczenie Biblii najważniejsze - wyraźnie wskazuje, że wolałby, aby Hieronim ,wiernie" oddał w języku łacińskim (Latinae ueritati reddideris) tekst Septuaginty, by łatwiej było wyłapać miejsca zepsute i nieprawdziwe ${ }^{35}$. Augustyn sugeruje zatem Hieronimowi, aby thumaczył tekst słowo w słowo. O braku dobrego tłumaczenia informuje Hippończyk w liście 261. Audacjusza, pisząc, że nie posiada tłumaczenia Psalmów z hebrajskiego autorstwa Hieronima, to zaś, które posiada, zawiera tekst skorygowany, wciąż z błędami i jeszcze niedoskonały, stąd konieczne są dalsze porównania istniejących wersji ${ }^{36}$. Więcej informacji o możliwym sposobie tłumaczenia zawarł Augustyn w liście 149. skierowanym do biskupa Paulina. Zauważa w nim, że gdyby próbować zróżnicować formy wypowiedzi w tłumaczeniu według właściwości języka łacińskiego, to odpowiadać to będzie wiedzy łacinników, ale z pewnością nie znaczeniu i sposobowi użycia tych wyrażeń w języku greckim. Dlatego też wskazuje na odpowiedni i jak najbliższy znaczeniem oryginałowi dobór słów w tłumaczeniu ${ }^{37}$.

Na większość uwag i zarzutów Augustyna odpowiada Hieronim - wprawdzie nie jemu samemu - w swych listach, ukazując jednocześnie swoją metodę tłumaczeniową. Wobec zarzutów o zmianę niektórych rzeczy w Ewangeliach wbrew powadze starych thumaczeń, w liście 27. napisanym do Marceli Hie-

\footnotetext{
si manifesta, illos in eis falli potuisse non creditur. Huius igitur rei pro tuo caritate, expositis causis, certum me facias obsecrauerim", thum. Eborowicz, s. 211-212.

${ }^{33}$ Spór, który powstaje pomiędzy Augustynem i Hieronimem, trwać będzie wiele lat. Augustyn bowiem nie może pogodzić się z wyborem Hieronima, aby nowe tłumaczenie łacińskie Biblii dokonać na bazie Biblii hebrajskiej. Augustyn wyraża w listach tezę o wyższości kościelnych autorytetów greckich i łacińskich nad oryginalnym tekstem Biblii, trudną do zaakceptowania nie tylko dla Hieronima, ale również z dzisiejszego punktu widzenia. Por. Y. Chauffin, Święty Hieronim, thum. B. Durbajło, Warszawa 1977, 195; E. Malfatti, Una controversia tra S. Agostino e S. Girolamo, Monza 1921; J. Czuj, Spór św. Augustyna ze św. Hieronimem. Studium biblijno-patrystyczne, Poznań 1934; K. Morta, Bluszcz kontra dynia, czyli trudne poczatki Wulgaty, „Theologica Wratislaviensia" 6 (2011) 91-120.

${ }^{34}$ Por. Augustinus, Epistula 71, 3.

${ }_{35}$ Tenże, Epistula 71, 6, CSEL 34/2, 254, thum. Eborowicz, s. 391.

${ }^{36}$ Por. tenże, Epistula 261, 5.

${ }^{37}$ Por. tenże, Epistula 149, 13.
} 
ronim w bardzo ostrych i emocjonalnych słowach przedstawia podstawy swej teorii thumaczenia:

„Nie jestem tak dalece tępy ani nie odznaczam się tak ordynarnym prostactwem [...] bym sądził, że należy cokolwiek ze słów Pańskich zmienić albo, że coś nie jest przez Boga natchnione, chciałem tylko błędy kodeksów łacińskich, o których świadczą różnice we wszystkich księgach, sprowadzić do źródła greckiego, z którego były przełożone, czemu i oni nie zaprzeczają"38.

Zadaniem zatem mądrego i wykształconego thumacza jest nie tylko thumaczenie i niezmienianie sensu tekstu, ale także korekta, jeżeli tekst ten jest zepsuty. Tłumacz Biblii ma także mieć świadomość, że jest to tekst natchniony. Jednak swoją pełną teorię translatoryki przedstawia Hieronim w liście 57, skierowanym do Pammachiusza, który to list nazywany jest często traktatem o najlepszym sposobie thumaczenia. W liście tym, w odpowiedzi na szyderstwa Rufina, że źle przetłumaczył list Epifaniusza do Jana Jerozolimskiego ${ }^{39}$, Strydończyk wyjaśnia najpierw, że list ten został mu wykradziony przed jego poprawieniem, a następnie, że najlepszym sposobem tłumaczenia jest właśnie ten, który zastosował do tego listu. Pisze:

„Ja bowiem nie tylko wyznaję, lecz wprost i otwarcie oświadczam, że w thumaczeniu pism greckich - wyjąwszy Pismo święte, gdzie i porządek słów jest tajemnicą - wyrażam nie słowo za słowem, lecz myśl za myślą"40.

Tłumacząc zatem Pismo Święte należy kierować się również porządkiem słów Pisma natchnionego, zaś tłumacząc dzieła świeckie należy tłumaczyć zgodnie z duchem tekstu, a nie układem słów. W kolejnych fragmentach swego listu Hieronim odwołuje się do własnego życia i sposobu tłumaczenia zawsze stosowanego przez niego oraz opisanego w innej rozprawie dotyczącej tłumaczeń:

„Ale by nie umniejszać powagi moich pism, chociaż to tylko chciałem wykazać, że zawsze od młodości nie słowa, lecz zdania przekładałem, zapoznaj się z moim poglądem na tę sprawę czytając małą przedmowę do książki o życiu błogosławionego Antoniego. «Dosłowny przekład z jednego języka na drugi zakrywa treść i jakby bujną trawą dusi zboże. Gdy bowiem mowa jest sługą przypadków i figur, wtedy to, co mogłoby być powiedziane krótko, z trudnością da się wyłuszczyć w długich i zawiłych wywodach. Tego więc unikając,

${ }^{38}$ Hieronymus, Epistula 27, 1, ŹMT 54, 122: „Non adeo hebetis fuisse me cordis, et tam crassae rusticitatis (quam illi solam pro sanctitate habent, piscatorum se discipulos adserentes, quasi idcirco sancti sint, si nihil scierint) ut aliquid de Dominicis verbis, aut corrigendum putaverim, aut non divinitus inspiratum; sed Latinorum codicum vitiositatem, quae ex diversitate librorum omnium comprobatur, ad Graecam originem, unde et ipsi translata non denegant”, ŹMT 54, 122*.

${ }^{39}$ Por. Kelly, Hieronim, s. 165-166.

${ }^{40}$ Hieronymus, Epistula 57, 5, ŹMT 55, 59: „Ego enim non solum fateor, sed libera voce profiteor me in interpretatione Graecorum, absque Scripturis sanctis, ubi et verborum ordo mysterium est, non verbum e verbo, sed sensum exprimere de sensu", ŹMT 55, 59*. 
tak - na twoją prośbą - przełożyłem Żywot błogosławionego Antoniego, że nic nie brakuje z treści, choć są braki w słowach. Niech inni łowią zgłoski i litery, ty szukaj zdań»"

Po raz kolejny zatem Hieronim podkreśla konieczność podążania w tłumaczeniu za myślą autora, a nie układem słów, i do takiego sposobu przekładania zachęca czytelnika swego listu. Ważne jest jednak dotarcie do jak najbliższego oryginałowi tekstu, aby móc skorygować ewentualne błędy i przetłumaczyć tekst jak najlepiej. Dlatego Hieronim w liście 106, w którym do Sunniasza i Fratelasa pisze o zepsutym tekście psalmów w wydaniu Septuaginty, wskazuje na sposób dotarcia do oryginału i wspomina o pracy z tekstem skażonym:

„Otóż, jeśli idzie o Nowy Testament, to w wypadku, gdy Łacinnicy mają wątpliwości, a między poszczególnymi egzemplarzami zachodzi różnica, uciekamy się do oryginalnego języka greckiego, w którym spisany został ten Nowy Dokument. Jeśli natomiast w zakresie Starego Testamentu zachodzi różnica między Grekami a Łacinnikami, wtedy zwracamy się do oryginału hebrajskiego, aby odszukać w strumykach to, co płynie ze źródła. Koine czyli powszechne wydanie, w zasadzie jest identyczne z Septuaginta, ale między jednym i drugim zachodzi taka różnica, że koine zależnie od miejsca, czasu i samowoli kopistów jest jednocześnie starym i zniekształconym wydaniem, natomiast tekst zawarty w Heksapli, będący podstawą mojego przekładu, jest identyczny z tym, który zachował się nieskażony w księgach uczonych mężów, z autentycznym przekładem Siedemdziesięciu Tłumaczy. Toteż nikt nie wątpi, że cokolwiek różni się od tego ostatniego, nie zgadza się również z oryginałem hebrajskim" 42 .

${ }^{41}$ Tenże, Epistula 57, 6, ŹMT 55, 60-61: „Verum ne meorum scriptorium parva sit auctoritas (quanquam hoc tantum probare voluerim, me semper ab adulescentia non verba, sed sententias transtulisse) qualis super hoc genere praefatiuncula sit, in libro quo beati Antonii vita describitur, ipsius lectione cognosce. «Ex alia in aliam linguam expressa ad verbum translation, sensum operit; et veluti laeto gramine, sata strangulat. Dum enim casibus et figuris servit oratio, quod brevi poterat indicare sermone, longo ambitu circumacta vix explicat. Hoc igitur ego vitans, ita beatum Antonium te petente, transposui, ut nihil desit ex sensu, cum aliquid desit ex verbis. Alii syllabas aucupentur et litteras, tu quaere sententias»", ŹMT 55, 60*-61*.

${ }^{42}$ Tenże, Epistula 106, 2, ŹMT 61, 124: „Sicut autem in Novo Testamento, si quando apud Latinos quaestio exoritur, et est inter exemplaria varietas, recurrimus ad fontem Graeci sermonis, quo novum scriptum est Instrumentum: ita et in veteri Testamento, si quando inter Graecos Latinosque diversitas est, ad Hebraicam confugimus veritatem; ut quidquid de fonte proficiscitur, hoc quaeramus in rivulis. Koıvท́ autem ista, hoc est Communis edition, ipsa est quae et Septuaginta. Sed hoc interest inter utramque, quod кoıvท́ pro locis et temporibus, et pro voluntate scriptorium, vetus corrupta editio est. Ea autem, quae habetur in $\dot{\varepsilon} \xi \alpha \pi \lambda \circ \hat{\imath} \varsigma$, et quam nos vertimus, ipsa est quae in eruditorum libris incorrupta et immaculata Septuaginta Interpretum translatio reservatur. Quidquid ergo ab hac discrepat, nulli dubium est, quin ita et ab Hebraeorum auctoritate discordet", ŹMT 61, 124*. Por. tenże, Epistula 112, 20. Zob. S. Leanza, Gerolamo e la tradizione ebraica, w: Motivi letterari ed esegetici in Gerolamo. Atti del convegno tenuto a Trento il 5-7 dicembre 1995, red. C. Moreschini - G. Menestrina, Religione e Cultura 9, Brescia 1997, 17-38. 
W dalszym ciagu listu Hieronim wskazuje również na konieczność zachowania przez thumacza przyjemnego brzmienia tekstu oryginału. Oczywiście nie chodzi o tłumaczenie dosłowne, ale o takie oddanie myśli za pomocą składni i idiomów języka, na który tłumaczony jest tekst, aby również w nim brzmiało to przyjemnie i z wdziękiem. Należy tłumaczyć zachowując eufonię i przez omówienie oraz stosując właściwości danego języka ${ }^{43}$.

Powyżej, w oparciu o listy dwóch bez wątpienia autorytetów, jeżeli chodzi o znajomość, thumaczenie i interpretację Pisma Świętego - św. Hieronima i św. Augustyna - przedstawiono, w jaki sposób wczesnochrześcijańscy tłumacze podchodzili do kwestii zasad translatorskich, które z nich stosowali, jakie zalecali i jak miały się one do metod wypracowanych przez pokolenia starożytnych filologów. Z pewnością jednak to, co najbardziej przemawia z powyższych rozważań, to ogromny szacunek do słowa, do prawdy i do człowieka, a przede wszystkim do Słowa Bożego. Wydaje się, że jest to także nauka dla współczesnych tłumaczy i badaczy Swiętych Ksiąg, ale nie tylko dla nich.

\section{THE BIBLE AND THE HOPE FOR ITS GOOD TRANSLATION}

\section{(Summary)}

In the above article, based on the correspondence of St. Jerome and St. Augustine, there has been shown how these two outstanding the Bible experts, translators and interpreters understood the principles used in its translation. In three parts - entitled: Work, Man, Way - the importance and significance of the Bible and its translations, above all the Septuagint, the tasks and features of the man who translates, the methods and ways of translating were shown. Both of them in their letters indicated: the necessity of an exceptional and proper approach to the Holy Scriptures, a good preparation of the translator and the use of a method that would be appropriate to the translated piece: in the case of the Bible - a beautiful translation preserving the arrangement of the words of the inspired Scriptures; and in the case of non-canonical pieces - expressing the thoughts using the rules of the language into which the work is translated.

Key words: Jerome, Augustine, Bible, translation, letters, Septuagint.

Słowa kluczowe: Hieronim, Augustyn, Biblia, thumaczenie, listy, Septuaginta.

\section{BIBLIOGRAFIA}

\section{Źródła}

Augustinus, Epistulae, CSEL 34/1-2, 44, 57, ed. A. Goldbacher, Vienna 1895-1911, tłum.

W. Eborowicz: Św. Augustyn, Listy (1-75), Pelplin 1983.

${ }^{43}$ Por. Hieronymus, Epistula 106, 3. 55. 
Hieronymus, Epistulae, ŹMT 54, 55, 61, 63, 68 [wyd. łacińsko-polskie, tłum. J. Czuj, oprac. H. Pietras - M. Ożóg, t. 1-5], Kraków 2010-2013.

\section{Opracowania}

Chauffin Y., Święty Hieronim, tłum. B. Durbajło, Warszawa 1977.

Chidester D.S., The Symbolism of Learning in St. Augustine, HTR 76 (1983) 73-90.

Cummings J.T., St. Jerome as Translator and as Exegete, StPatr 22 (1975) 279-282.

Czuj J., Spór św. Augustyna ze św. Hieronimem. Studium biblijno-patrystyczne, Poznań 1934.

De BRuYNe D., La correspondence échangée entre Augustin et Jérôme, ZNW 31 (1932) 233-248.

EcKmann A., Hieronim ze Strydonu. Nauka $w$ stużbie rozumienia i interpretacji Pisma Świętego, AK 422 (1979) 422-429.

Gamberale L., Problemi di Gerolamo traduttore fra lingua, religione e filologia, w: Cultura latina cristiana. Fra terzo e quinto secolo. Atti del Convegno, Mantova, 5-7 novembre 1998, ed. C. Gallico, Firenze 2001, 311-345.

Gamberale L., San Gerolamo. Intellettuale e filologo, Storia e Letteratura 282, Roma 2013.

Gilbert M., Saint Jérôme, traducteur de la Bible, w: tenże, Il a parlé par les prophètes. Thèmes et figures bibliques, Namur 1998, 9-28.

Haitjema T., De briefwisseling tuschen Augustinus en Hieronymus, „Tijdschrift voor Geschiedenis" 36 (1921) 159-198.

Kelly J.N.D., Hieronim. Życie, pisma, spory, tłum. R. Wiśniewski, Warszawa 2003, 163 192.

KöpF U., Hieronymus als Bibelübersetzer, w: Eine Bibel - Viele Übersetzungen. Not und Notwendigkeit, hrsg. S. Meurer, Stuttgart 1978, 71-89.

Malfatti E., Una controversia tra S. Agostino e S. Girolamo, Monza 1921.

Meershoek G.Q.A., Le latin biblique d'après saint Jérôme, Latinitas Christianorum Primaeva 20, Nijmegen - Utrecht 1966.

Meiser M., Hieronymus als Textkritiker, w: Die Septuaginta - Texte, Theologien, Einflüsse. 2. Internationale Fachtagung veranstaltet von Septuaginta Deutsch (LXX.D), Wuppertal 23.-27. Juli 2008, hrsg. W. Kraus - M. Karrer - M. Meiser, Wissenschaftliche Untersuchungen zum Neuen Testament 252, Tübingen 2010, 256-271.

Morta K., Bluszcz kontra dynia, czyli trudne poczatki Wulgaty, „Theologica Wratislaviensia" 6 (2011) 91-120.

Pontet M., L'exégèse de St. Augustin predicateur, Paris 1945.

Simonetti M., Między dostownościa a alegoriq. Przyczynek do historii egzegezy patrystycznej, tłum. T. Skibiński, Kraków 2000, 347-364.

Spychąa D., Św. Hieronim i św. Augustyn wobec tlumaczeń Biblii i literatury antycznej, „Saeculum Christianum” 15 (2008) 2, 5-13.

Torscher F.E., The Correspondence of St. Augustine and St. Jerome. A Study, „,The American Ecclesiastical Review" 57 (1917) 476-492. 
